\title{
An alternative classification of occupational hand injuries based on etiologic mechanisms: the ECOHI classification
}

\author{
Etyolojik mekanizmalarının temelinde iş kazasına bağlı el yaralanmalarında \\ alternatif bir sınıflama: İKEYES sınıflaması
}

\author{
Bülent ÖZÇELIK, ${ }^{1}$ Erden ERTÜRER, ${ }^{2}$ Berkan MERSA, ${ }^{1}$ Hüsrev PURİSA, ${ }^{1}$ İlker SEZER, ${ }^{1}$ \\ Serdar TUNÇER, ${ }^{3}$ Fatih KABAKAŞ, ${ }^{1}$ Samet Vasfi KUVAT ${ }^{4}$
}

\section{BACKGROUND}

The aim of this study was to construct an alternative classification system for occupational hand injuries based on etiologic mechanisms and to analyze the injury patterns resulting from various mechanisms.

\section{METHODS}

A retrospective analysis of patients operated between January 2005 and December 2007 in two hand surgery units staffed by a team of hand surgeons was made. The patient files were retrospectively examined, and mechanisms causing the injuries were analyzed. Similar mechanisms were classified in the same groups, and the mechanism of injury was matched with type of injury often caused by this mechanism. In the classification of injuries, the tissues that were injured were taken as a basis for classification. 4120 upper extremity injuries were seen in the study hospitals, and $2188(53.1 \%)$ of them were occupational injuries. There were 2063 males (94.3\%) and 125 females $(6.7 \%)$. The mean age was 28.2 (range: $15-71$ ) years.

\section{RESULTS}

Examination of the agents causing injury yielded 62 agents. Further examination of these agents showed that the mechanism by which they caused injury was similar in some agents, and these agents were placed in the same groups, which constituted the Etiologic Classification of Hand Injuries (ECOHI) classification. These groups of mechanisms were: cutting-penetrating, cutting-crushing, crushing-penetrating, crushing-compressing, crushing-burning, stinging, avulsing, electrical current, and chemical injuries and miscellaneous burns. The two most common mechanisms were crushing-compressing and cutting-crushing types, constituting $744(34.0 \%)$ and $514(23.5 \%)$ of injuries, respectively.

\section{CONCLUSION}

We believe that ECOHI is important to form a common language for the classification of etiologic factors.

Key Words: Occupational hand injuries; etiologic classification.

\section{$\boldsymbol{A M A C}$}

Bu çalışmanın amacı, etyolojik mekanizmalarına bağlı olarak iş kazalarına bağlı el yaralanmaları için alternatif bir s1niflama sistemi ortaya koymaktır.

\section{GEREÇ VE YÖNTEM}

İki el cerrahisi ünitesi cerrahlarınca, Ocak 2005 ile Aralık 2007 yılları arasında ameliyat edilen hastaların geriye dönük olarak analizleri yapıldı. Hasta dosyaları retrospektif incelendi ve yaralanmaya neden olan mekanizmalar incelendi. Benzer yaralanma mekanizmaları aynı gruplarda s1nıflandırıldı ve görülme sıklıkları araştırıldı. Yaralanmaların sinıflandırılmasında hasarlanan dokular temel alındı. Hastaneye yatırılan 4120 el cerrahisi hastasından $2188^{\prime}$ 'i $(\% 53,1)$ iş kazası sonucu yaralanan olgular idi. Bunların 2063'ü erkek $(\% 94,3), 125$ 'i kadındı $(\% 6,7)$. Ortalama yaş 28,2 (dağılım 15-71 yaş) idi.

\section{BULGULAR}

Yaralanmaya neden olan ajanların incelenmesinde 62 ajan belirlendi. Bu ajanların ileri incelemesi ile benzer yaralanmaya neden olan ajanlar "iş kazalarına bağlı el yaralanmalarının etyolojik sınıflandırması"na (İKEYES) göre gruplandırıldı. Bu grupları kesici-delici, kesici-ezici, ezici-delici, ezici-sıkıştırıcı, ezici-yakıcı, batıcı, avulziyon, elektrik çarpması ve kimyasal yaralanmalar ve diğer yanıklar oluşturdu. Etyolojideki en sık iki mekanizmayı 744 $(\% 34,0)$ olgu sayısı ile ezici-sıkıştırıcı yaralanmalar ile 514 $(\% 23,5)$ olgu sayısı ile kesici-ezici yaralanmalar oluşturmaktayd1.

\section{SONUÇ}

İKEYES sınıflamasının literatürde etyolojik faktörlerin s1nıflaması için ortak bir dil oluşturulabilmekte önemli olduğuna inanmaktayı.

Anahtar Sözcükler: İş kazalarına bağlı el yaralanmaları; etyolojik siniflama.

\footnotetext{
${ }^{1}$ İst-el El Cerrahisi, Mikrocerrahi ve Rehabilitasyon Grubu, İstanbul;

${ }^{2}$ Şişli Etfal Eğitim ve Araştırma Hastanesi, Ortopedi ve Travmatoloji Kliniği, İstanbul; ${ }^{3}$ İstanbul Bilim Üniversitesi Tıp Fakültesi,

Plastik, Rekonstrüktif ve Estetik Cerrahi Anabilim Dalı, İstanbul; ${ }^{4}$ İstanbul Üniversitesi İstanbul Tıp Fakültesi, Plastik, Rekonstrüktif ve Estetik Cerrahi Anabilim Dalı, İstanbul.
}

\footnotetext{
${ }^{1}$ Ist-el Hand Surgery, Microsurgery and Rehabilitation Group, Istanbul;

Şişli Etfal Training and Research Hospital, Orthopedic Clinic and Traum
Clinic, Istanbul; ${ }^{3}$ Department of Plastic, Reconstructive and Aesthetic

Surgery, Istanbul Bilim University, Istanbul; ${ }^{4}$ Department of Plastic, Reconstructive and Aesthetic Surgery, Istanbul University,
} Istanbul Faculty of Medicine, Istanbul, Turkey. 
The International Labour Organization (ILO) defines occupational accident as "an unexpected and unplanned occurrence, including acts of violence, arising out of or in connection with work, which results in a personal injury, disease or death..$^{[1,2]}$ According to the ILO data, 270 million occupational accidents annually result in the death of 5000 and 2,000,000 million people every day and every year, respectively. Occupational accidents also cause significant financial and work losses. In the United States per se, financial losses due to fatal and non-fatal occupational accidents were 145.37 billion USD in 1992. ${ }^{[3]}$ Therefore, prevention of these accidents carries great significance. Unfortunately, despite developments in health and safety systems, the frequency of occupational accidents remains high. ${ }^{[4,5]} \mathrm{In}$ a retrospective analysis of health-related social security benefits, occupational injuries constituted $7.3 \%$ of all benefits due to health problems and illnesses. ${ }^{[6]}$

Work-related hand injuries constitute a major portion of occupational accidents and range from simple skin lacerations to amputations. ${ }^{[7]}$ Classifications and scoring systems are helpful in predicting the outcomes of injury in addition to the assessment of their severity. ${ }^{[8]}$ Although numerous classification systems and scales have been developed for injuries of the lower extremity, their equivalents for the upper extremity are limited. ${ }^{[8,9]}$ The most commonly used scoring system in hand injuries is the Hand Injury Severity Score (HISS), developed by Campbell and Kay in 1996. ${ }^{[10]}$ Other scoring systems in hand injuries are also based on severity of the injury, and the mechanism of the injury is often not considered in these systems. However, the mechanism of injury is significant in determining the type and severity of injury. The definition and classification of these mechanisms is an important step in the formation of a common language, which will assist in studies that will determine the etiologies of occupational accidents and in strategies to decrease their occurrence. Using our database on occupational injury, the aim of this study was to construct an alternative classification system for occupational hand injuries based on etiologic mechanisms and to analyze the injury patterns resulting from the various mechanisms. Therefore, it is different from previous classification systems because of its particular emphasis on the mechanism of injury.

\section{MATERIALS AND METHODS}

A retrospective analysis of patients operated between January 2005 and December 2007 in two hand surgery units staffed by a team of hand surgeons was made. These hand surgery units serve as tertiary referral centers for upper extremity injuries, and owing to their proximity to industrial regions of the city, they provide care for a wide spectrum of occupational hand injuries. The patient files were retrospectively examined, and mechanisms causing the injuries were analyzed. Similar mechanisms were classified in the same groups, and the mechanism of injury was matched with type of injury often caused by this mechanism. In the classification of injuries, the tissues that were injured were taken as a basis for classification.

\section{RESULTS}

During the study period, 4120 upper extremity injuries were seen in the study hospitals, and 2188 (53.1\%) of them were occupational injuries. There were 2063 males $(94.3 \%)$ and 125 females $(6.7 \%)$. The mean age was 28.2 (range: 15-71) years. The dominant zone for the injury is zone II in the classification based on flexor zones of the hand.

Examination of the agents causing injury yielded 62 agents, including glass, cleaver, rivet, hot press, needle, stair, electricity, and hot water, etc. Further examination of these agents showed that the mechanism by which they caused injury was similar in some agents, and these agents were placed in the same groups, which constituted the Etiologic Classification of Hand Injuries (ECOHI) classification. These groups of mechanisms were: 1. Cutting-penetrating, 2. Cutting-crushing, 3. Crushing-penetrating, 4. Crushing-compressing, 5. Crushing-burning, 6. Stinging, 7. Avulsing, 8. Electrical current, and 9. Chemical injuries and miscellaneous burns (Table 1). The two most common mechanisms were crushingcompressing and cutting-crushing types, constituting $744(34.0 \%)$ and $514(23.5 \%)$ of injuries, respectively, whereas burn injury was the least common mechanism, causing injury in 11 patients $(0.52 \%)$. The most common injury type in crushing-compressing mechanism was tendon laceration+vessel and/or nerve injury+fracture $(35.1 \%)$. The most common type of injury in cutting-crushing type mechanism was tendon lacerations + fracture $(33.9 \%)$. Burns caused tissue defects (Table 2). Among all patients, the most common type of injury was simultaneous injury of the tendons, nerves, vessels, and bones. This was followed by amputations in 372 patients, and isolated nail bed injuries in 275 patients (Table 3 ).

\section{DISCUSSION}

Occupational accidents constitute $6.6 \%$ - $28.6 \%$ of all diseases, and are the leading causes of death or severe disability. ${ }^{[1-13]}$ Cooperation between clinicians, employers, labor organizations, and Ministries of Health is necessary to decrease the incidence of occupational injuries. The execution of most daily and work activities depends on the hand; therefore, it is the most common body part injured in occupational accidents. The hands are involved in $35.3 \%$ to $53.1 \%$ of occupational injuries. ${ }^{[14,15]}$ 
Table 1. Etiologic classification of injuries

\begin{tabular}{llllllllll}
\hline Etiologic classification & \multicolumn{1}{l}{} & & & & \\
\hline 1 & 2 & 3 & 4 & 5 & 6 & 7 & 8 & 9 \\
\hline $\begin{array}{l}\text { Cutting - } \\
\text { Penetrating }\end{array}$ & $\begin{array}{l}\text { Cutting- } \\
\text { Crushing }\end{array}$ & $\begin{array}{l}\text { Crushing- } \\
\text { Penetrating }\end{array}$ & $\begin{array}{l}\text { Crushing- } \\
\text { Compressing }\end{array}$ & $\begin{array}{l}\text { Crushing- } \\
\text { Burning }\end{array}$ & Penetrating & $\begin{array}{l}\text { Avulsion } \\
\text { type }\end{array}$ & $\begin{array}{l}\text { Electric } \\
\text { Injury }\end{array}$ & Burns \\
\hline 471 & 514 & 353 & 744 & 41 & 21 & 19 & 14 & 11 \\
$21.52 \%$ & $23.49 \%$ & $16.13 \%$ & $34 \%$ & $1.87 \%$ & $0.89 \%$ & $0.87 \%$ & $0.64 \%$ & $0.52 \%$ \\
\hline
\end{tabular}

\section{Etiologic agents}

\begin{tabular}{|c|c|c|c|c|c|c|c|c|}
\hline Glass & Cleaver & Rivet & Press & Hot press & Needle & Ladder & Electricity & $\begin{array}{l}\text { Scalding } \\
\text { burn (water) }\end{array}$ \\
\hline Metal sheet & Axe & Snap fastener & Cylinder & Injection & Iron fragment & Ring & & Fire burn \\
\hline Tin & Milling machine & Drill & Wringer & Oven lid & Splinter & Elevator & & $\begin{array}{l}\text { Chemical } \\
\text { burn }\end{array}$ \\
\hline Knife & Buzz saw & Nail & Machine & Flat iron & & & & \\
\hline Tile & Stone motor & Shaping saw & Door-Window & & & & & \\
\hline Guillotine & $C_{t}+1$ & & & & & & & \\
\hline $\begin{array}{l}\text { (Publishing) } \\
\text { Mould }\end{array}$ & Strap-belt pulley & & & & & & & \\
\hline Scissors & Chain & & Hammer & & & & & \\
\hline Hook & Sandpaper & & Stone & & & & & \\
\hline & Cogwheel & & Marble & & & & & \\
\hline & Saw & & Package & & & & & \\
\hline & Propeller & & Timber & & & & & \\
\hline & Cable & & Seat - chair & & & & & \\
\hline & Spiral saw & & Packing machine & & & & & \\
\hline & Carpenter's plane & & Mill & & & & & \\
\hline & Plate sheet cutter & & Scanning machine & & & & & \\
\hline & Lawnmower & & Vise & & & & & \\
\hline & $\begin{array}{l}\text { Chopping machine } \\
\text { Grinding machine }\end{array}$ & & Mold & & & & & \\
\hline
\end{tabular}

The nature of hand injuries caused by occupational accidents differs with respect to the developmental level of the country and regional differences in the type of industry within the same country. In a large retrospective analysis involving 37,405 nonfatal occupational accidents, Layne et al. ${ }^{[15]}$ investigated occupational injuries in the United States within a six-month period during 1992, and found that finger and hand injuries were the most common, with a rate of $44.3 \%$. The authors reported that the most common injury types were lacerations and burns, with rates of $39.0 \%$ and $17.7 \%$, respectively. According to Birgen et al., ${ }^{[14]}$ in areas where heavy industry is predominant, the fingers and the hand were injured most commonly (48.6\%), yet the most common type of injury was amputation due to industrial machines $(38.3 \%)$. In our study, the most common mechanisms were crushing-compressing and cutting-crushing types, and the most common injuries were tendon laceration+vessel and/or nerve injury+fracture and tendon laceration + fracture.

In addition to the nature of the work, there are numerous factors that affect the frequency and nature of accidents, which include low age of the workers, inadequate knowledge of the machine, inadequate experience, and lack of attention. ${ }^{[5,16]}$ Accidents among adolescent workers are common, and their fatality is greater. ${ }^{[17]}$ Absoud and Harrop ${ }^{[18]}$ analyzed 73 patients and found that the underlying cause of the accident was inadequate knowledge of the machine they were operating in $14 \%$. Considering that age and experience are closely related, they should be evaluated together. In our patient group, most injuries occurred in patients aged 25-30 years. The injuries were relatively less common in patients under age 15; however, they were mostly mutilating hand injuries. Patients over 50 years of age often had minor injuries.

Numerous classification and scoring systems have been developed for hand injuries. The most widely known of these are the mutilating hand classification of Campbell Reid, ${ }^{[19]}$ and the Hand Injury Severity Score (HISS) scoring of Campbell and Kay. ${ }^{[10,20]}$ Campbell Reid ${ }^{[19]}$ in his book on 'mutilated hands', classified these injuries in five groups as: dorsal injuries, palmar injuries, radial hemi-amputation, ulnar hemi-amputation, and distal amputation. This clas- 
Table 2. The lesion types and numbers of patients for each injury

\begin{tabular}{|c|c|c|c|c|}
\hline Group & Lesion & $\begin{array}{c}\text { Number of } \\
\text { patients }\end{array}$ & $\%$ & $\begin{array}{l}\text { Zone of } \\
\text { injury }\end{array}$ \\
\hline \multirow[t]{4}{*}{ Cutting-penetrating injuries $(\mathrm{n}=471)$} & Skin laceration alone & 184 & 39.06 & I \\
\hline & Tendon+vessel+nerve injury & 152 & 32.27 & II \\
\hline & Amputation & 71 & 15.07 & II \\
\hline & Other & 64 & 13.6 & I \\
\hline \multirow{4}{*}{ Cutting-crushing injuries $(n=514)$} & Tendon laceration+fracture & 174 & 33.85 & II \\
\hline & Fracture alone & 122 & 23.73 & II \\
\hline & Amputation & 93 & 18.09 & II \\
\hline & Other & 125 & 24.33 & $\mathrm{I}$ \\
\hline \multirow[t]{4}{*}{ Crushing-penetrating injuries $(n=353)$} & Fracture alone & 102 & 28.89 & III \\
\hline & Nail bed injury alone & 81 & 23.07 & I \\
\hline & Tendon laceration+fracture & 70 & 19.83 & II \\
\hline & Other & 100 & 28.21 & II \\
\hline \multirow[t]{4}{*}{ Crushing-compressing injuries $(n=744)$} & Tendon+vessel+nerve injury+fracture & 261 & 35.08 & III \\
\hline & Amputation & 178 & 23.94 & II \\
\hline & Nail bed injury alone & 116 & 15.59 & $\mathrm{I}$ \\
\hline & Other & 189 & 25.41 & II \\
\hline \multirow[t]{4}{*}{ Crushing-burning injuries $(n=41)$} & Fracture + tissue defect & 14 & 34.14 & II \\
\hline & Tissue defect alone & 10 & 24.89 & III \\
\hline & Compartment syndrome & 8 & 19.51 & $\mathrm{~V}$ \\
\hline & Other & 9 & 21.96 & II \\
\hline \multirow[t]{3}{*}{ Penetrating injuries $(n=21)$} & Skin laceration alone & 10 & 47.64 & II \\
\hline & Nerve injury alone & 9 & 42.85 & II \\
\hline & Tissue defect alone & 2 & 9.51 & III \\
\hline \multirow[t]{2}{*}{ Avulsion injuries $(n=21)$} & Amputation & 12 & 63.15 & II \\
\hline & Tissue defect alone & 7 & 36.85 & $\mathrm{I}$ \\
\hline \multirow[t]{2}{*}{ Electric injuries $(n=14)$} & Tissue defect alone & 10 & 71.43 & $\mathrm{I}$ \\
\hline & Amputation & 4 & 28.57 & II \\
\hline Chemical burns $(\mathrm{n}=11)$ & Tissue defect alone & 11 & 100 & $\mathrm{I}$ \\
\hline
\end{tabular}

* Dominant flexor zone for the injury.

sification is helpful in the determination of treatment strategies. However, it is not quantitative and involves only mutilating hand injuries and anatomic areas. Based on 100 patients, Campbell and Kay ${ }^{[10]}$ developed a scoring system (HISS) that can be used in injuries distal to the carpal bones, and this is the most widely known severity scoring system. Other scoring systems used commonly for determining the severity of hand injuries are Tamai's score ${ }^{[21]}$ and the Quick DASH score. ${ }^{[22]}$ These systems are based on healing and prognosis, and although they are used frequently, there is no widely accepted etiologic classification. The tic-tac-toe classification is used for the classification of mutilating hand injuries using orientation,

Table 3. Detailed injury types

\begin{tabular}{|c|c|c|c|c|c|}
\hline Injury type & $\begin{array}{c}\text { Number of } \\
\text { patients }\end{array}$ & $\%$ & Injury type & $\begin{array}{c}\text { Number of } \\
\text { patients }\end{array}$ & $\%$ \\
\hline Tendon+vessel+nerve injury+fracture & 381 & 17.41 & Compartment syndrome & 14 & 0.64 \\
\hline Amputation & 372 & 17.00 & Nerve injury alone & 12 & 0.55 \\
\hline Nail bed injury alone & 275 & 12.56 & Vascular injury alone & 11 & 0.5 \\
\hline Tendon laceration+fracture & 266 & 12.15 & Tendon+vessel injury & 11 & 0.5 \\
\hline Fracture alone & 240 & 10.96 & Vessel+nerve injury & 10 & 0.45 \\
\hline Skin laceration alone & 203 & 9.27 & Tendon+nerve injury & 9 & 0.41 \\
\hline Tendon+vessel+nerve injury & 146 & 6.67 & Vessel+nerve injury+tissue defect & 8 & 0.40 \\
\hline Tendon laceration alone & 117 & 5.34 & Fracture+nerve injury & 6 & 0.39 \\
\hline Fracture+tissue defect & 58 & 2.65 & Fracture + nerve injury & 4 & 0.37 \\
\hline Tissue defect alone & 45 & 2.05 & & & \\
\hline
\end{tabular}


wound type and zone of injury. ${ }^{[23]}$ This classification separates the etiologic mechanisms according to soft tissue loss, bone loss, combined tissue loss, and vascularized or devascularized tissues; however, because it focuses on mutilating hand injuries, it does not represent a wide spectrum of etiologic factors. The ECO$\mathrm{HI}$ classification presented here was developed on the basis of a large series of patients and includes a wide selection of mechanisms.

The International Classification of External Causes of Injuries (ICECI) is a very detailed classification system of external causes. ${ }^{[2]}$ It is useful in epidemiological studies. ${ }^{[25]}$ However, it is too long and detailed to form a common language for the classification of etiologic factors in hand injuries. Also, it is not aimed to classify occupational hand injuries; therefore, it covers all types of injuries, including poisoning, falling, drowning, and even exposure to low gravity. The ECOHI classification proposed in this study is brief and easy to learn and forms a common language between hand surgeons.

There are numerous mechanisms for injury in the workplace. The 2188 patients involved in this study were injured by 62 separate agents. The seven groups of the etiologic classification were developed considering the injury mechanisms of these agents. Agents that have the potential to cause injury, yet were not included in our database, can be added to appropriate groups.

The two most common mechanisms for injury in our ECOHI classification were crushing-compressing and cutting-crushing type injuries, and the two most common injury types were tendon+vessel+nerve+bone injuries and amputations. The ECOHI classification does not give information on the severity or the prognosis of injury, which constitutes one of the weaknesses of the study. This is due to inadequate data regarding the functional outcomes of the patients. Nevertheless, we believe that such a classification is important to form a common language for the classification of etiologic factors.

\section{REFERENCES}

1. International Labour Organization, Statistics of occupational injuries. Report III, Sixteenth International Conference of Labour Statisticians. Geneva, 6-15 October 1998. http:// www.ilo.org/public/english/bureau/stat/download/16thicls/ report3.pdf. (Accessed online on 08.11.2010)

2. Hijioka A, Narusawa K, Nakamura T. Risk factors for longterm treatment of whiplash injury in Japan: analysis of 400 cases. Arch Orthop Trauma Surg 2001;121:490-3.

3. Leigh JP, Markowitz SB, Fahs M, Shin C, Landrigan PJ. Occupational injury and illness in the United States. Estimates of costs, morbidity, and mortality. Arch Intern Med 1997; 157:1557-68.

4. Altan L, Akin S, Bingöl U, Ozbek S, Yurtkuran M. The prog- nostic value of the Hand Injury Severity Score in industrial hand injuries. Ulus Travma Acil Cerrahi Derg 2004;10:97101.

5. Tan KK, Fishwick NG, Dickson WA, Sykes PJ. Does training reduce the incidence of industrial hand injuries? J Hand Surg Br 1991;16:323-6.

6. Santana VS, Araújo-Filho JB, Albuquerque-Oliveira PR, Barbosa-Branco A. Occupational accidents: social insurance costs and work days lost. [Article in Portuguese] Rev Saude Publica 2006;40:1004-12.

7. Nelson NA, Park RM, Silverstein MA, Mirer FE. Cumulative trauma disorders of the hand and wrist in the auto industry. Am J Public Health 1992;82:1550-2.

8. Matsuzaki H, Narisawa H, Miwa H, Toishi S. Predicting functional recovery and return to work after mutilating hand injuries: usefulness of Campbell's Hand Injury Severity Score. J Hand Surg Am 2009;34:880-5.

9. Yokoyama K, Itoman M, Nakamura K, Uchino M, Nitta H, Kojima Y. New scoring system predicting the occurrence of deep infection in open upper and lower extremity fractures: efficacy in retrospective re-scoring. Arch Orthop Trauma Surg 2009;129:469-74.

10. Campbell DA, Kay SP. The Hand Injury Severity Scoring System. J Hand Surg Br 1996;21:295-8.

11. Dias JJ, Garcia-Elias M. Hand injury costs. Injury 2006;37:1071-7.

12. Mathur N, Sharma KK. Medico-economic implications of industrial hand injuries in India. J Hand Surg Br 1988;13:3257.

13. Chan JC, Ong JC, Avalos G, Regan PJ, McCann J, Groarke $\mathrm{A}$, et al. Illness representations in patients with hand injury. $\mathrm{J}$ Plast Reconstr Aesthet Surg 2009;62:927-32.

14. Birgen N, Yavuz MS, Okyay M. The medico-legal evaluation of occupational injuries. [Article in Turkish] J Forensic Medicine 2001;15:14-8.

15. Layne LA, Castillo DN, Stout N, Cutlip P. Adolescent occupational injuries requiring hospital emergency department treatment: a nationally representative sample. Am J Public Health 1994;84:657-60.

16. Ünlü RE, Abacı Ünlü E, Orbay H, Şensöz Ö, Ortak T. Crush injuries of the hand. Ulus Travma Acil Cerrahi Derg 2005;11:324-8.

17. Castillo DN, Landen DD, Layne LA. Occupational injury deaths of 16- and 17-year-olds in the United States. Am J Public Health 1994;84:646-9.

18. Absoud EM, Harrop SN. Hand injuries at work. J Hand Surg Br 1984;9:211-5.

19. Campbell Reid DA. Severely mutilated hand. In: Campbell Reid DA, Tubiana R, editors. Mutilating injuries of the hand. London: Churchil Livingstone, Longman Group Ltd; 1979. p. 3-14.

20. van der Molen AB, Matloub HS, Dzwierzynski W, Sanger JR. The hand injury severity scoring system and workers' compensation cases in Wisconsin, USA. J Hand Surg Br 1999;24:184-6.

21. Tamai S. Twenty years' experience of limb replantation-review of 293 upper extremity replants. J Hand Surg Am 1982;7:549-56.

22. Imaeda T, Toh S, Wada T, Uchiyama S, Okinaga S, Kusunose $\mathrm{K}$, et al. Validation of the Japanese Society for Surgery of the 
Hand Version of the Quick Disability of the Arm, Shoulder, and Hand (QuickDASH-JSSH) questionnaire. J Orthop Sci 2006;11:248-53.

23. Weinzweig J, Weinzweig N. The "Tic-Tac-Toe" classification system for mutilating injuries of the hand. Plast Reconstr Surg 1997;100:1200-11.
24. http://www.rivm.nl/who-fic/ICECI/ICECI 1-2 2004 July.pdf. (Accessed at 28.09.09).

25. Davas Aksan A, Durusoy R, Ada S, Kayalar M, Aksu F, Bal E. Epidemiology of injuries treated at a hand and microsurgery hospital. Acta Orthop Traumatol Turc 2010;44:35260. 